International Background Paper

Wealth Tax Commission

\title{
Wealth tax: India
}

Authors

Girish Vanvari

Krishnan TA OF ECONOMICS AND POLITICAL SCIENCE

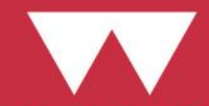
WARWICK 


\section{WEALTHTAX: INDIA}

Girish Vanvari, Transaction Square LLP

Krishnan TA, Transaction Square LLP

Wealth Tax Commission Background Paper no. 137

Published by the Wealth Tax Commission

www.ukwealth.tax 


\section{Acknowledgements}

The Wealth Tax Commission acknowledges funding from the Economic and Social Research Council (ESRC) through the CAGE at Warwick (ES/L011719/1) and a COVID-19 Rapid Response Grant (ES/V012657/1), and a grant from Atlantic Fellows for Social and Economic Equity's COVID-19 Rapid Response Fund. 


\section{Brief history of wealth tax in India}

After Indian independence in 1947, the Indian Income Tax Act 1922 was the principal legislation governing the levy of direct taxes. With the Nehru-led Government in power, the trend in the economy in the initial years after independence was towards greater socialism. There was a progressive taxation regime with higher taxes being levied on the rich. There were many problems in the Indian direct tax system resulting in heavy tax evasion. Therefore, the Government of India set up the Kaldor Committee in 1955 to rationalise the tax system and bring about affirmative reforms. Pursuant to the suggestions made by the Kaldor Committee, the Government delineated a plan for a composite and integrated tax structure to ensure that no income or wealth escaped assessment. Thus, the Wealth Tax Act (WTA) (धन कर अधिनियम) was introduced in 1957 as a permanent measure. It was abolished in 2015 due to several procedural difficulties such as extensive litigation, increased compliance burdens, heavy administration costs and generation of inadequate revenues. There is currently no real support to reintroduce the wealth tax.

In recent years, the wealth tax raised revenue as follows:

TABLE 1: REVENUE RAISED BY WEALTHTAX

\begin{tabular}{|c|c|c|c|}
\hline Year & $\begin{array}{c}\text { Collection } \\
\text { (Indian Rupees (billions)) }\end{array}$ & Year & $\begin{array}{c}\text { Collection } \\
\text { (Indian Rupees (billions)) }\end{array}$ \\
\hline 2003-04 & 1.36 & $2009-10$ & 5.05 \\
\hline 2004-05 & 1.45 & 2010-11 & 6.87 \\
\hline $2005-06$ & 2.50 & $2011-12$ & 7.87 \\
\hline 2006-07 & 2.40 & 2012-13 & 8.44 \\
\hline $2007-08$ & 3.40 & 2013-14 & 10.07 \\
\hline 2008-09 & 3.89 & 2014-15 & 10.86 \\
\hline
\end{tabular}

Source: https://www.indiabudget.gov.in/

When the wealth tax was introduced in India in 1957, the taxation system in India had multiple taxes coupled with high rates. Such a structure was more coercive rather than progressive and was leading to economic instability. In 1991, India decided to liberalise its economic and fiscal policies to attract global capital. In 1993, the WTA was modified to cover only unproductive and idle assets, previous to which it was levied on all assets of an assessee. As per the observations made by successive committees set up by the Government in the post-liberalisation era, the levy faced several administrative challenges such as extensive litigation on valuation matters, insufficient tax yield, high costs of administration etc. Considering all the aforesaid factors, the Government, with effect from April 2015, decided to abolish the levy of wealth taxes in India. As a measure to partly offset the revenue loss on account of the abolishment of wealth tax, the Government decided to increase the surcharge levied taxes on the wealthiest individuals by an incremental rate of $2 \%$ in the same year.

The objective of a direct taxation regime is to ensure progressiveness in the levy of taxes, i.e. tax the rich and incentivise the poor to achieve higher degrees of economic equality. This predominantly makes the levy of such a tax justifiable. However, when such a progressive taxation regime imposes heavy rates of taxes even at moderately high levels of income, it may be perceived as unfair. One of the major problems in India up till the 1990s, was the excessively high rates of taxes which led to large scale evasion.

Until 1991, the business environment was largely dominated by public sector undertakings and the policy framework was not friendly towards private enterprises. Thus, even though wealth 
tax had a negative impact on entrepreneurship, it was part of the policy objectives of the government in power at the time, which justified the levy.

However, after 1991, the laws were amended to embrace globalisation, prompting a drastic reduction in the scope of wealth tax so that it covered only unproductive and idle assets, and thus did not prevent the promotion and incentivisation of start-ups.

The tax was levied over the whole of India at a uniform rate, including in the Union Territories of Jammu \& Kashmir and Ladakh. Note that there are now no annual taxes remaining on ownership of real estate and shares in India. 


\section{What assets were taxed? Exemptions and reliefs}

When the WTA was introduced in 1957, all assets unless specifically excluded were subject to wealth tax. Subsequently, due to policy changes of the Government after the globalisation of the Indian economy in 1991 (see above), the scope of the wealth tax was limited to only a few specified assets. This largely dealt with liquidity and valuation problems. The same is covered in detail in Table 2 below.

\section{TABLE 2: COVERAGE OF WEALTH TAX}

\begin{tabular}{|c|c|}
\hline Before 1993 & After 1993 \\
\hline $\begin{array}{l}\text { All kinds of property excluding only: } \\
\text { i) agricultural land and growing crops, grass or } \\
\text { standing trees on such land; } \\
\text { ii) any building owned or occupied by a } \\
\text { cultivator of, or receiver of rent or revenue } \\
\text { out of, agricultural land; } \\
\text { iii) animals; } \\
\text { iv) right to any annuity in any case where the } \\
\text { terms and conditions relating thereto } \\
\text { preclude the commutation of any portion } \\
\text { thereof into a lump sum grant; } \\
\text { v) any interest in property where the interest } \\
\text { is available to an assessee for a period not } \\
\text { exceeding six years from the date the interest } \\
\text { vests in the assessee; } \\
\text { vi) pensions. }\end{array}$ & 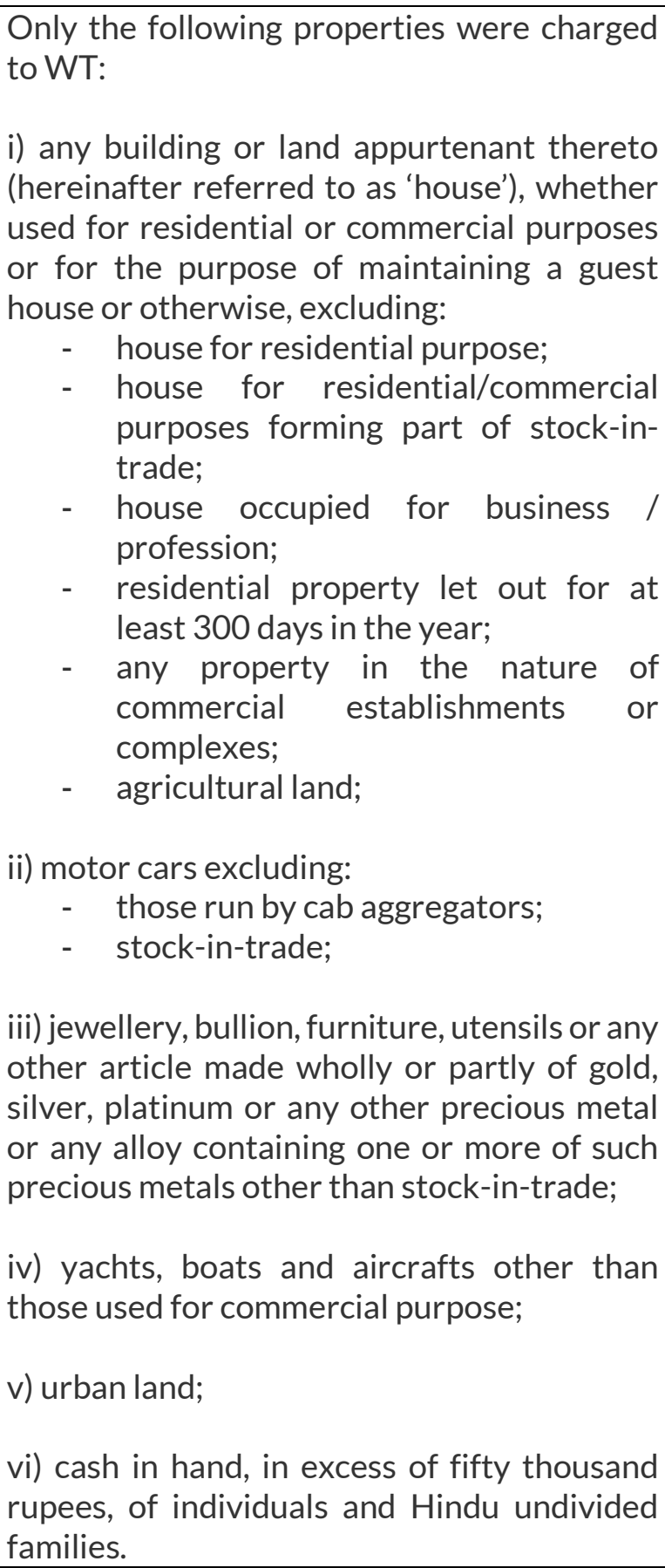 \\
\hline
\end{tabular}

Special exemption was also given in case of Gold deposit bonds issued under the Gold Deposit Scheme of 1999 by the Government of India. Pensions were exempt. 


\section{Defining the tax base}

Every individual, Hindu undivided family and company excluding:

- non-profit organisations incorporated as companies

- any co-operative society

- any social club

- any political party

- a specified Mutual Fund

- the Reserve Bank of India incorporated under the Reserve Bank of India Act, 1934

was subject to wealth tax on his net wealth on the last day of a financial year.

\section{Individuals and families}

As a general rule, tax was levied on wealth per individual. However, in certain circumstances, the wealth of the spouse and children was included in the wealth of said individual. In the case of a minor child, his wealth was included with that of the parent having higher net wealth. Also, if any property was transferred by a person to his spouse for inadequate or no consideration, the same was included in the wealth of such individual.

Wealth was computed based on title to the property. In the case of joint titles of family members, a pro ratacalculation was made.

\section{Trusts}

As a general rule, trusts, other than charitable or religious trusts, were chargeable to wealth tax. However, if certain guidelines, predominantly pertaining to utilisation of assets held by the trust for prescribed charitable or religious purposes were not complied with, then tax could be levied even on such charitable or religious trusts. The following principles should be noted:

(1) The status of the settlor was irrelevant in determining the taxability of the assets held in trust.

(2) In the case of determinate trusts (those where the shares of each beneficiary were clearly defined and demarcated), the liability devolved on the trustee in the like manner and same extent as it would devolve upon the beneficiaries. If the value of interests of the beneficiaries fell short of the value of the underlying assets held in trust, such excess value was taxable on the trustee as if he were a separate individual.

(3) In the case of indeterminate trusts (discretionary trusts), the entire wealth tax was levied on the trustee assessed as an individual. The trustee had the right to recover the amount of the tax paid from the beneficiary or from the trust fund. 


\section{Territoriality}

\section{Non-residents}

Wealth of non-residents, in the form of any asset situated in India, was subject to tax in India. In the case of enveloped vehicles, the immediate holder entity, was taxed on its assets situated in India. A non-resident was not subject to wealth tax on global wealth even if he was an Indian citizen.

There was an exemption from wealth tax for assets located outside India in case of persons who were not recognised as '"residents' as per the residency rules in India. Normally, a non-resident person becoming an Indian resident was treated as remaining a 'not ordinarily resident' for approximately three years. In effect then, for the first three years after immigration to India, unless the person was an Indian national, wealth tax did not apply except in relation to India situated assets.

This did not change between regions or cantons or depending on whether someone is on the forfait or fixed rate charge.

\section{Individuals leaving India}

No exit taxes on wealth were levied if an individual left India.

In the case of residents, worldwide wealth was taxed in India, while in the case of non-residents, only wealth situated in India was taxed.

Typically, in the case of an Indian national leaving India, there is a taper of four years, i.e. for four years after his exit from India, he would have been liable to wealth tax on his global wealth in India since he would be recognised as a 'tax resident' during this period as per the residency guidelines, even after his departure from India. 


\section{Valuation issues}

New valuations of an individual's wealth were required every year. As a general rule, assets were valued at their net realisable value. However, special computational provisions were prescribed for valuation of specific assets, such as immovable properties, jewellery, interest in partnership firms, assets of a business and life interests.

No specific rules were prescribed for the valuation of minority shares. The proportionate value of the company was attributed to the value of the minority interests pro rata.

Valuations could take a long time due to complex calculations prescribed under the law and were also prone to extensive litigation.

A main residence (self-occupied property) was exempted from the computation of net wealth. Other assets exempted were those held in trusts for charitable or religious purposes and interests in Hindu undivided families (see table above).

All chargeable assets were valued at net realisable value. 


\section{Liquidity concerns}

Where wealth tax was due on illiquid assets in cases where the taxpayer had little income (such as a large house owned by a person with little income) the revenue authorities had the right to permit an assessee to pay the tax in instalments. Also, any interest on non-payment of tax could be waived at the sole discretion of the assessing officer. (The main residence was exempt anyway).

\section{Reliefs}

Public and charitable trusts were exempted from wealth tax subject to compliance with prescribed conditions.

All agricultural assets were excluded from the ambit of wealth tax in India.

A deduction was given with respect to debt incurred in relation to the acquisition of assets liable to wealth tax. 


\section{Relationship with other taxes}

When the WTA was introduced in India, as part of a comprehensive scheme of taxation, gift tax, inheritance tax and expenditure taxes were concurrently introduced. Capital gains tax (CGT) was already in place in India prior to the introduction of said taxes. However, most of these taxes have now been abolished. Currently, only CGT as part of income tax is in force. Today, there is no tax in India levied on wealth or expenditure. Estate duty was also abolished in 1985.

Each tax had its own separate computational provisions. Wealth tax and income tax were not based on the same tax base.

\section{Reliefs and rates}

In all the above taxes, agricultural assets were exempted altogether. Also, charitable and religious trusts were exempt subject to satisfaction of prescribed conditions. Apart from the general reliefs, specific policy related reliefs such as direct taxation on Special Economic Zones, Export Oriented Units and Domestic Tariff Areas were granted a general exemption.

Inheritance tax rates were progressive and rose as high as $85 \%$ on estates exceeding 2 million Indian rupees. Gift tax rate was $30 \%$ on the donation, with a basic exemption of 30,000 Indian rupees.

Wealth tax was not deductible or creditable against any other tax. Relief was not given against wealth tax for charitable donations, although a deduction for charitable gifts was given under the income tax regime.

One of the primary objectives for the introduction of wealth tax was to obtain information that could be used in other areas of the tax system. However, such information sharing did not bring about the desired results in terms of revenue. 


\section{Planning and enforcement/collection and assessment}

\section{Avoidance and non-compliance}

In order to avoid wealth tax legally, people typically used to generate income from immovable properties such as rent.

As per the interim report of the Tax Reforms Committee, large scale evasion of wealth tax was taking place in India during the late 1980s. Although no numbers were provided in this report, the yield of the wealth tax was observed to be significantly lower than expected, indicating large scale evasion.

Targeted anti-abuse rules have been in force a long time in India. However, they never covered wealth taxes.

\section{Collection and assessment}

Assessment of wealth taxes was based on self-assessment, with cases then chosen for selective scrutiny. An assessee had to file an annual return along with the tax payable which would then be scrutinised by the revenue authorities.

The administrative costs were believed to be high for both taxpayers and the Revenue. Thresholds for reporting were the same as thresholds for the payment of wealth tax (see below).

The Revenue authorities could reopen any assessments within four years. Taxpayers could amend a return within one year. Penalties and interest provisions (and indeed enforcement generally) were similar to those used for income tax.

Actual payment of the tax was made before the filing of the return. The Revenue had wide powers to audit and investigate returns (although the actual annual number is unknown), including requiring the taxpayer to produce his account books, sign statements of declaration of wealth, and conduct searches for unreported wealth.

\section{Wealth tax appeals}

An order passed by the Assessing Officer was first appealable to the Commissioner (Appeals). Such orders could be challenged in the Income-tax Appellate Tribunal, and thereafter in the High Court and Supreme Court of India. Alternatively, an assessee could also make an application to the Wealth Tax Settlement Commission constituted under the WTA when any proceeding against the taxpayer was pending at the Assessing Officer level. 


\section{Wealth tax rates and bands}

Until 1993, the rates were set at a progressive basis. However, thereafter, a flat rate of $1 \%$ was charged on net wealth above a specified threshold. This was initially 1.5 million rupees, later increased in 2010 to 3 million rupees. The rates of income tax and wealth taxes were therefore quite separate. The above thresholds compute to about 15,665.79 British pounds and $31,331.59$ British pounds respectively. There was no cap on the wealth tax. There was no cap or relief if the person had no income but sufficient wealth to pay wealth tax. 